\title{
A historical, scaled approach to climate change adaptation: the case of Vietnam
}

\author{
Lily Lindegaard ${ }^{1}$ \\ Danish Institute for International Studies, Denmark
}

\begin{abstract}
This article sheds light on how scaled, historical dynamics inform the framing of climate change adaptation programs. It looks particularly at the influence of domestic versus global rationalities in adaptation programs through a novel joint governance and political ecology framework. It does this in the setting of water management in Vietnam. Based on a historical view, semi-structured interviews and document and policy reviews, I examine historical water management in Vietnam and current water management programs identified as climate change adaptation. By analyzing how historical, scaled political rationalities inform the framing of current adaptation programs, I find that program formulation reflects domestic(ated) rationalities rather than novel global adaptation agendas. This suggests that universalizing accounts of climate change adaptation overlook the significance of situated, historical factors in the formulation of adaptation programs. Furthermore, the article illustrates how political rationalities can be rescaled, gaining traction within new institutional scales and the programs enacted from them. Finally, the article underlines the inherent power implications of the struggle to determine whose rationalities prevail in program formulation.
\end{abstract}

Keywords: Climate change adaptation, water management, scale, rescaling, political rationalities, Vietnam

\section{Résumé}

Cet article met en lumière la façon dont les dynamiques historiques à l'échelle influencent l'élaboration des programmes d'adaptation au changement climatique. Il examine en particulier l'influence des rationalités nationales par rapport aux rationalités mondiales dans les programmes d'adaptation à travers un nouveau cadre conjoint de gouvernance et d'écologie politique. Elle le fait dans le cadre de la gestion de l'eau au Vietnam. Sur la base d'une vision historique, d'entretiens semi-structurés et d'examens de documents et de politiques, j'examine la gestion historique de l'eau au Vietnam et les programmes de gestion de l'eau actuels identifiés comme " l'adaptation au changement climatique ". En analysant comment les rationalités historiques et politiques à différentes échelles éclairent l'élaboration des programmes d'adaptation actuels, je trouve que la formulation des programmes reflète des rationalités nationales plutôt que de nouveaux programmes d'adaptation mondiaux. Cela suggère que dans les comptes rendus universalisants de l'adaptation au changement climatique, l'importance des facteurs historiques situés dans la formulation des programmes d'adaptation est négligée. En outre, l'article illustre comment les rationalités politiques peuvent être rééchelonnées, à de nouveaux niveaux institutionnels et dans les programmes qui en découlent. Enfin, l'article souligne les implications inhérentes des luttes de pouvoir sur les décisions concernant les rationalités qui prévalent dans la formulation des programmes. Mots-clés: adaptation au changement climatique, gestion de l'eau, échelle, rééchelonnement, rationalités politiques, Vietnam

\section{Resumen}

Este artículo explica cómo dinámicas históricas escaladas informan sobre la manera en que se enmarcan los programas de adaptación al cambio climático. Se enfoca particularmente en la influencia de las racionalidades domésticas sobre las globales dentro de los programas de adaptación, esto, a través de un marco novedoso conjunto entre gobernanza y ecología política. El trabajo se encuentra enfocado en el manejo de agua en

\footnotetext{
${ }^{1}$ Dr Lily Salloum Lindegaard, Researcher, Natural Resources and Development unit, Danish Institute for International Studies, Østbanegade 1172100 Copenhagen Ø, Denmark. Email: lili "at" diis.dk. Acknowledgements: I would like to express my gratitude to all of those who shared their time and insights during interviews and who provided access to the documents that enabled this research. I would also like to thank my colleagues at Hue University of Agriculture and Forestry for supporting this research, as well as Mikkel Funder and Christian Lund for their input to earlier drafts of this article.
} 
Vietnam. Con base en una perspectiva histórica, entrevistas semiestructuradas y revisión documental y de políticas, se examina el manejo histórico del agua en Vietnam, así como los actuales programas de manejo identificados como de adaptación al cambio. Analizando cómo las racionalidades políticas históricas escaladas configuran el marco de los programas de adaptación actuales, encuentro que la formulación de programas refleja una racionalidad doméstica(da), más que una basada en las novedosas agendas globales de adaptación. Esto sugiere que las perspectivas que tienden a universalizar la adaptación al cambio climático, pasan por alto el valor de los factores locales e históricos para la formulación de programas de adaptación. Más allá, el artículo ilustra cómo las racionalidades políticas pueden ser modificadas en su escala para generar fuerza dentro de nuevos niveles institucionales y en los programas que se establezcan por su parte. Finalmente, el artículo destaca las implicaciones inherentes al poder en el forcejeo para determinar cuáles racionalidades prevalecen en la formulación de los programas.

Palabras clave: Adaptación al cambio climático, manejo de agua, escala, modificación de escala, racionalidades políticas, Vietnam.

\section{Introduction}

Climate change adaptation programs are proliferating. However, the complex and deeply political nature of adaptation is often overlooked (Bassett and Fogelman 2013; Eriksen et al. 2015; Taylor 2015). Climate change adaptation encompasses inherent tensions: climate change is a global phenomenon with diverse local impacts. It intersects with policies and programs at and across various scales, and its impacts are informed by situated historical dynamics of environmental management, commercial investment, and socio-political relations (Adger et al. 2005; Taylor 2015: 17-18). Adaptation to climatic change as it is experienced through such mediating factors is inherently a question of governance - of managing people, land and resources (Taylor 2015: 18-19). Despite this, climate change adaptation efforts have evidenced a 'here and now' approach in which understanding how these situated historical dynamics influence adaptation has taken a back seat to the push from practitioners, political authorities, and academics to 'Adapt now!' (Leary et al. 2007). This is reflected by the relatively limited scholarly literature on the domestic politics of climate change adaptation (exceptions include Artur and Hilhorst 2012; Eriksen et al. 2015; Funder et al. 2018; Ojha et al. 2016; Smucker et al. 2015). This is in comparison to a greater focus on global climate policy, the mitigation of climate change rather than adapting to it (Bulkeley 2005; Hall and Persson 2017; Javeline 2014).

It is therefore increasingly vital to examine how diverse interests and influences shape adaptation efforts. In this article I focus specifically on the interplay between global and domestic interests in the formulation of adaptation programs. To do so, I develop a novel approach based on a joint governance and political ecology framework. On the governance side, I draw on the work of Rose and Miller (1992). They examine how political authorities problematize and manage a variety of topics and activities such as health, poverty or sexuality. They describe how programs of government - those programs implemented by political authorities - are tangible translations of political epistemologies and norms, which they call political rationalities. Studying climate change adaptation programs can therefore provide insight into which rationalities adaptation programs propagate and instantiate, and this has implications for adaptation broadly and in particular, program impacts. On the political ecology side, the article adopts a historical, scaled perspective and applies it to climate change adaptation rationalities and programs. Combining these two literatures allows for exploring scale in terms of governance, particularly, the (re)scaling of political rationalities and implications for governance programs. It does this in the context of water management in Vietnam.

Vietnam is projected to be one of the countries most affected by climate change, both in terms of extreme weather events (Kreft et al. 2016) and gradual climate change impacts (Wong et al. 2014). In Vietnam's Thua Thien Hue Province, or Hue Province, the geographic focus of this article, climate change is felt through sea level rise, changing precipitation patterns and swinging temperatures (CCAP 2012; Potsdam Institute 2013). Political authorities are implementing water management programs as adaptation, among a variety of other responses (Hue People's Committee 2007). At the same time, Vietnam has a long history of water management, which is so tightly intertwined with the country's governance, that it has been referred to as a 'hydraulic bureaucracy' (Evers and Benedikter 2009) and 'hydrocracy' (Benedikter 2014b). Vietnam therefore provides an excellent case for examining the influence of historical domestic dynamics versus novel global adaptation rationalities in the formulation of adaptation programs. 
The following conceptual section expounds on the historical, scaled approach to examining governmental rationalities and programs. The article presents the examination of water management in Vietnam in two parts. First, a historical section outlines the development of water management in Vietnam through to its current dominance; to illustrate the analytical approach, it details the prevailing governmental rationalities and programs for each historical period. Secondly, I examine contemporary water management programs used as climate change adaptation in Hue Province. I consider current water management generally and present the specific program of Thao Long Dam, a salinity prevention dam whose complex history illustrates the importance of an extended temporal viewing of seemingly novel adaptation programs. The analysis draws on the robust literature on historical water management in Vietnam, review of documents and policies, and semistructured interviews held with provincial, district, and commune officials and water management practitioners.

The article's findings suggest that programs of adaptation may well reflect domestic(ated) political rationalities rather than novel global agendas. This emerges from the more general conclusion that pre-existing environmental management dynamics strongly drive current climate change adaptation initiatives. These findings suggest that global climate change adaptation agendas may not easily influence program formulation unless they have been adopted at the scale of formulation. However, the analysis also demonstrates how rationalities can be rescaled, gaining traction within new scales and the programs enacted from them. Ultimately, the article underlines how those defining climate change adaptation interventions define others' lived realities. It joins the growing body of literature that highlights the inherently political nature of climate change adaptation.

\section{The analytical approach}

The approach of the article - to analyze how scaled, historical political rationalities inform adaptation programs - draws on both governance and political ecology literature, and intersects with water management and climate change literatures. Below, I highlight relevant literature in more detail and outline my approach.

\section{Governance perspective}

Political rationalities and programs are key aspects of Rose and Miller's (1992) account of 'problematics of government.' These authors build on the work of Michel Foucault (e.g. Foucault 1991) and approach governance through the exercise of power rather than state structures. In this approach, government is conceptualized as "the historically constituted matrix within which are articulated all those dreams, schemes, strategies and maneuvers of authorities that seek to shape the beliefs and conduct of others...by acting upon their will, their circumstances or their environment" (Rose and Miller 1992: 175). Within this, 'political rationalities' provide the conceptual and moral foundation for the activity of government, which I refer to as 'governance.' Political rationalities have linguistic, epistemological, and moral aspects, providing the language to describe the reality to be governed, conceptions of what is to be governed, and principles and goals of how and to what ends these things are to be governed. While political rationalities are not fixed or beyond contestation, some gain more support and prominence than others and are expressed tangibly through programs of government (Rose and Miller 1992). Rose and Miller describe this movement from abstract rationalities to concrete programs as one of translation, "both a movement from one space to another, and an expression of a particular concern in another modality" (Rose and Miller 1992: 181). In the setting of water management infrastructure, these could be exemplified by political rationalities of physical security from storms being translated into concrete programs of dyke construction.

The article's analysis of the relationship between political rationalities and programs of water management in Vietnam draws on the extensive literature on the country's historic water management (e.g. Biggs et al. 2009; Evers and Benedikter 2009; Fforde 2010; Fontenelle 2001). In addition, it builds on subnational data collection, with focus on the political rationalities evidenced in policies, official documents and interviews with sub-national bureaucrats. Sub-national bureaucrats, in this case at provincial, district and commune levels, play a central role in program formulation and implementation (Lipsky 1980), so their rationalities can be extremely important for the tangible programs implemented and outcomes of the same. These data sources are supplemented by analysis of Vietnamese climate change adaptation policies (e.g. Zink 2013). 


\section{Political ecology perspective}

Political ecology as a discipline grew out of the need for an analytical approach combining environmental and political perspectives (Bryant 1992; Bryant and Bailey 1997). It draws on political economy and ecology, though contains diverse approaches within this broad framing. These approaches share a common understanding of environmental problems as the "manifestation of broader political and economic forces" (Bryant and Bailey 1997: 3), produced through the historic interplay of these forces across spatial scales. A political ecology approach to adaptation has been comprehensively elaborated by Marcus Taylor (2015), who illustrates the historical and diversely scaled political and economic forces shaping how climate change is experienced, understood and acted on. This work, as well as political ecology's theorizing on scale, offer important contributions to the article's analytical approach.

Since the 1990s, discussions of scale have increasingly challenged seemingly fixed labels of, for example, local, national and global. Scholars have illustrated how scales are socially and politically constructed as well as contested and reformed in what is called rescaling (see Brenner 2001: 591-592; Norman et al. 2012: 53-54). These critical discussions have extended through political ecology (Neumann 2009) and increasingly into water management literature (Mollinga 2008; Norman et al. 2012). This literature works, among other things, to clarify what the politics of scale means in water management (Lebel et al. 2005; Moss and Newig 2010; Norman et al. 2012); emancipate analyses of scale from the constructed fixity of river basins and watersheds (Feitelson and Fischhendler 2009; Molle 2009); and interrogate how the management of water resources contributes to rescaling (Budds and Hinojosa 2012; Johnson 2012; Norman and Bakker 2009). The article draws on this literature in its consideration of scalar influences in Vietnamese water management, specifically how differently-scaled management rationalities influence the types of programs instantiated. It applies political ecology's extensive theorizing on scale, specifically rescaling, to an adaptation context. Rescaling describes the "continuous reshuffling and reorganization of spatial scales" (Swyngedouw 2004: 33), a concept I use here to describe the movement of rationalities between institutional scales of governance (drawing, for example, on the rescaling of regulatory practices as described by Swyngedouw 2004: 37).

Within adaptation work, discussions of scale are growing (Adger et al. 2005). Adaptation has often been presented either as a large-scale phenomenon requiring global action and policy tools or as a local phenomenon predicated upon endogenous capacities and norms. The former takes its starting point in understandings of climate change itself as shared global phenomenon, a culmination of global environmentalist discourses (Jasanoff 2004) and global climate change discourses more particularly (Miller 2004). The latter emphasizes the localized nature of changes to the climate, the role of local socio-economic dynamics in determining how climate changes are felt, and the centrality of local institutions and politics in determining adaptation outcomes (Agrawal 2010; Miller 2004). It is reflected in community-based adaptation (Ayers and Forsyth 2009) and discussions of 'autonomous adaptation', implicit in which is a focus on individuals and communities (Forsyth and Evans 2013). Generally, the two discourses have not intersected, and the role of other scales in adaptation initiatives have only begun to be explored more recently (Adger et al. 2005; Urwin and Jordan 2008). Overall, critical reflection on scale in adaptation remains limited. Existing literature tends to focus on adaptation at a particular scale (Cartwright et al. 2013; Jeffers 2011) rather than across scales (Adger et al. 2005). Attention to the latter is growing, particularly regarding cross-scalar governance of adaptation (see e.g. Amundsen et al. 2010; Juhola and Westerhoff 2011), yet these are often practice-oriented accounts. Critical consideration of how and to what extent rationalities move between scales - and implications for adaptation policy, programming and outcomes - remains lacking. The article aims to address this gap.

\section{The joint approach}

This article draws on the literature described above to facilitate a joint governance and political ecology approach. Specifically, integrating rescaling with the activity of government helps explain how political rationalities from different scales influence adaptation programming and how these are rescaled over time. This approach highlights how power, in the form of dominant political rationalities, is manifested in the process of adaptation programming. This is reflected in the politicized knowledge and discursive aspects of climate change adaptation. That is, in whose rationalities come to dominate or, through the lens of political ecology, the "manner in which power relations may be reflected in conflicting perceptions, discourses and knowledge claims about development and ecological processes" (Bryant 1998: 87). In formal adaptation initiatives, the application of particularly scaled language, epistemologies, and morals structures the lives of those targeted and colors 
adaptation efforts more broadly. This is not to attribute undue moral or epistemological fixity to rationalities emanating from certain scales, but to acknowledge 'regularities' (Rose and Miller 1992: 178). Regularities are evident, for instance, in normative global governance discourses within international development, which have often closely cleaved to neoliberal epistemologies and ideals (Rose 1999: 16). Such neoliberal regularities are also emerging within both academic (see Bassett and Fogelman 2013) and practitioner-oriented adaptation literature (see Taylor 2015: 83-84), with fundamental consequences for how adaptation is understood and what forms it takes.

In terms of scale, the article's approach allows for a consideration of whether concrete adaptation programs reflect globally or domestically scaled rationalities and the implications this has for adaptation. While local and global influences are not mutually exclusive in adaptation, the weighting of one over the other will necessarily impact the framing of climate change adaptation needs and solutions as well as outcomes and implications. This binary may seem a conceptual blunt object, ignoring the produced nature of scales and the diversity of rationalities within certain scales. However, the basic distinction underlines the point I aim to make, namely that the scale of the political rationalities framing adaptation programs matter. They entail moral, epistemological, and linguistic regularities with ramifications for both adaptation and governance more generally. This particularism challenges the 'here and now' of dominant climate change adaptation discourses, which divorces adaptation from "trajectories of socio-ecological change that have a longer time frame and whose causative forces stretch beyond the places in which they manifest themselves" (Taylor 2015: 64). The article therefore critiques the assumptions of prevalent understandings of climate change adaptation; that is, for instance, as a universally applicable framework of local vulnerability to an external shock, as laid out in authoritative IPCC reports (Field et al. 2014), or as a set of global solutions that should be cascaded down through fixed scales (Bulkeley 2005).

The article's joint approach also requires a historical perspective. This proceeds from the understanding that adaptation enters into and interacts with existing social, political and ecological relations, which are themselves the product of long, often contentious histories (see Taylor 2015: 122-142). In addition, the 'rescaling' of political rationalities entails a temporal as well as a scalar movement. This requires a historical approach, which is central to the governance and political ecology literatures I draw on. Rose and Miller describe government as a "historically constituted matrix" (1992: 175) and political ecologists recognize environmental change as precipitated by historical dynamics including social relations, trading practices, practices of subsistence or accumulation, and political marginalization and control (Bryant and Bailey 1997).

\section{Water management historically}

This section traces the scaled political rationalities of water management programs from the earliest Vietnamese civilization to the present hydraulic bureaucracy. The review proceeds through precolonial, colonial, and communist periods. The precolonial section illustrates the long history and political import of water management in Vietnam. The colonial outlines the implementation of colonial exploitation and modernist conceptions of development through water management, with far-reaching consequences for the built environment as well as social, economic and political relations. The communist details how global communist rationalities of high modernism were domesticated and how water management programs became a tool for state-building. Overall, the section illustrates both the power of political rationalities to shape the built environment through political programs and the rescaling of political rationalities over time.

\section{The precolonial period}

Precolonial water management unfolds in two distinct periods. The first is the early pre-colonial period, in which the Vietnamese civilization was located in the Red River Delta of what is now northern Vietnam. A distinct Vietnamese civilization has been identified by historians as emerging in the Red River Delta at around 2000 to 1400 BC (Cima 1987). At this time, rationalities of physical and food security translated into programs of dykes and irrigation. By the sixth century BC, "an important aspect of this culture [...] was the tidal irrigation of rice fields through an elaborate system of canals and dikes. The fields were called Lac fields, and Lac, mentioned in Chinese annals, is the earliest recorded name for the Vietnamese people" (Cima 1987: 1). Wet rice cultivation necessitated some level of water management in the turbulent climate of northern Vietnam, where the annual rainy season brings powerful typhoons and huge volumes of water (Porter 1993: 1). Protective 
infrastructure was needed to prevent devastation of settlements, to enable wet rice agriculture, and to prevent the destruction and unrest that accompanied floods and resulting famines. Early water management thus coalesced around rationalities of securing physical and food security. It also formed a basis for political authority. The building and maintenance of water management infrastructure helped legitimize central political authorities and the structures of taxation such infrastructure required (Cima 1987). The water environment and management of the same were thus foundational aspects of life, political organization, and political rationalities in the Red River Delta.

The second period is that of southwards movement of the Vietnamese, when a rationality of territorial expansion was translated into programs of irrigation and canals. Around 1000 AD the Vietnamese people began an extended southward movement from the Red River Delta termed nam tien (Cima 1987). This movement brought with it the customs of wet rice production and associated irrigation schemes along the coastal plains of Vietnam (Hardy 2005: 4). Vietnamese settlers reached the Mekong Delta in the 17th century, which was at that time a sparsely-populated part of the Khmer empire (Biggs 2012). Here, water management again played a role in the extension of central authority as the Vietnamese emperors expanded their territorial control through strategic hydraulic works, particularly canals that aided in transport (such as the Bao Dinh canal) or supported settlement and territorial security (the Thoai Ha and Vinh Te canals) (Biggs 2012; Dieu 1999). The map of current-day Vietnam in Figure 1 below illustrates areas of interest in red - the Red River Delta in the north, the Mekong Delta in the south, and Hue Province located centrally along the coast. The red edging along the coastline illustrates the path of population movement during nam tien.

The significance of programs of water management and their governance for the Vietnamese state historically led to what Benedikter (2014) terms the 'hydraulic paradigm' as an organizing principle of society and state. In the precolonial period, this paradigm was driven by domestic political rationalities of security and territorial expansion translated into water management programs of dykes, irrigation, and canals.

\section{The colonial period}

The second half of the 1800s heralded the beginnings of colonial influence as French forces gained a foothold in the Mekong Delta. In this period, global colonial rationalities of exploitation and modernist development were translated into large-scale dredging programs. Exploitation and development first required control, which the French gained by expanding their military and transport capabilities in the Mekong Delta; they initially used established waterways and canals and later dredged new routes of transport and access (Biggs 2012). In 1879, French engineers began developing a plan for water management of the delta, ushering in ideals of environmental control through master planning (Brocheux and Hémery 2009). This reflected the modern conceptions of nature as an input to growth and progress (Uggla 2010) as well as the high modernist "aspiration to the administrative ordering of nature and society" (Scott 1998: 88). Between 1890 and 1910, over $165 \mathrm{Mm}^{3}$ of soil was dredged as waterways were expanded, extended and constructed (Biggs et al. 2009. In comparison, the Panama Canal required dredging $210 \mathrm{Mm}^{3}$, Biggs 2012: 42-43). Dredges, "more than gunboats, locomotives, or machine guns...meant immediate ecological and social change" (Biggs 2012: 43). This modernist approach and the ramifications it would have on the water environment, modes of production, and administration entailed a new era in the relationship between nation and nature (Ehlert 2012).

The canals enabled both exploitation and purported development by providing transport and drastically expanding access to land which could be used for agriculture. They were supplemented by new modes of exploitation through changed land and labor relations, which allowed for double-cropping and dramatic increases in rice production (Biggs 2012; Brocheux and Hémery 2009: 121-122). In the 1930s, however, economic recession and a build-up of social grievances and ecological problems in the colony of Indochina led to increasing challenges to French rule. Colonial administrators, in turn, pointed directly to their achievements of hydraulic management and booms in rice production, population and cultivated land as proof of the development their presence had wrought (Biggs 2012: 87-89). Colonial dredging, while offering the vehicle for the expansion of the colonial state, also came to be used as a justification for its presence. Rationalities of high modernism continued to inform hydraulic planning and interventions in the southern Republic of Vietnam under American involvement (Biggs 2006). This was partly due to constraints of earlier hydraulic interventions that had left their imprint on the landscape, but was also driven by American adherence to the 'hydraulic mission' of 
high modernist management and the Confucian authoritarian-style rule of the government in the south (Biggs 2008; Reis 2012: 36).

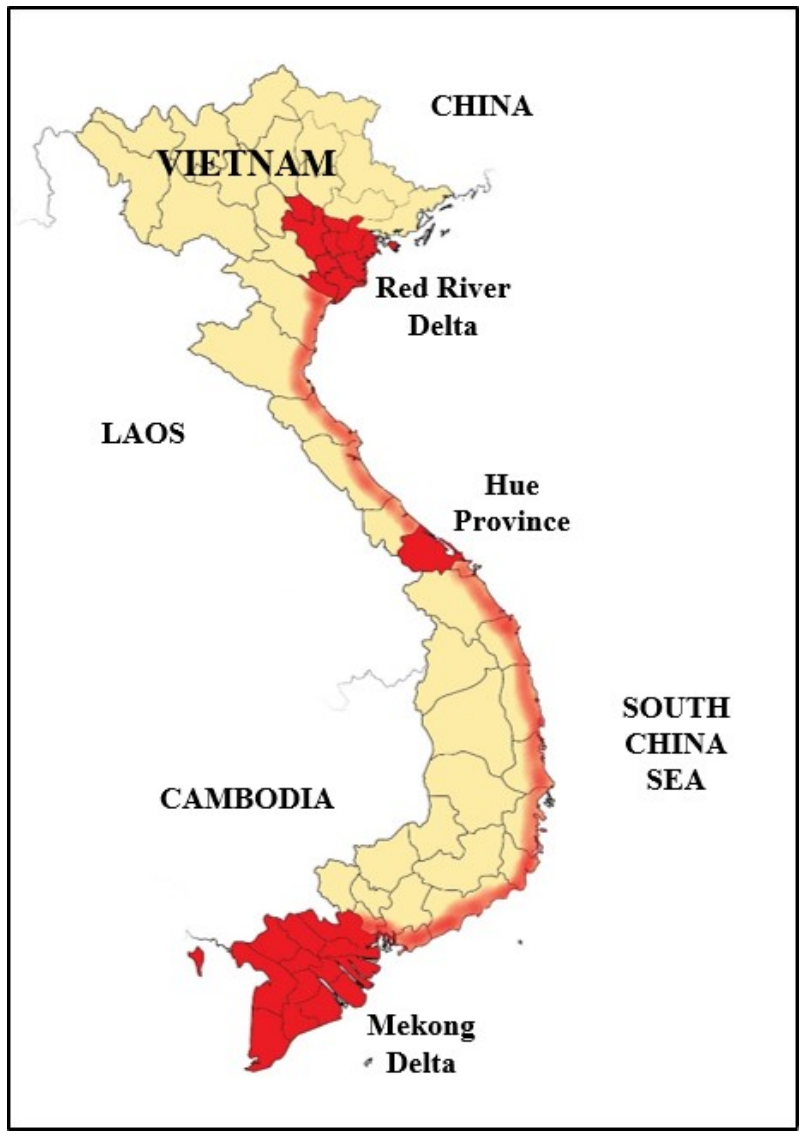

Figure 1: Map of Vietnam, showing regions discussed in the text.

These global colonial rationalities of exploitation and high modernist development led to programs that were much less compatible with local conditions than previous water management programs driven by domestic rationalities. This was partially due to the scale of such interventions under high modernist programs. While the Vietnamese had also built canals to aid in transport and territorial control, the French and later the Americanbacked administration extended this system significantly and, in doing so, disturbed the carefully balanced ecological, social, and economic conditions that had already been constructed (Biggs 2012: 41). It was also due to diverging perspectives inherent in local rationalities versus those of global high modernism. The latter viewed nature as something to be ordered by human administration, whereas local rationalities generally accepted the limitations of human interventions. This was evident in divergent perceptions of the silted 'dead points' that quickly built up in canals, sometimes rendering them impassable. Colonial engineers understood these as hindrances, but locals considered them meeting points and places to stop and rest on a journey. This reflected the more general approach of living with natural water flows instead of trying to manage them (Biggs 2012: 32-34).

The communist period

In the new Democratic Republic of Vietnam (DRV) established in the north of Vietnam in 1945, domestic rationalities of state-building informed and hinged on water management infrastructure. Declassified 
American intelligence reports following the development of the DRV in the 1950s give valuable insights into the role of irrigation at that time (Table 1). Rationalities of political control, social stability, food security, and economic development all coalesce in the water management of this period. They supported the broad goal of state-building through agricultural collectivization (Fontenelle 2001) and were in turn supported by the French and earlier Vietnamese hydraulic interventions on which they often were founded (Fforde 2010).

\begin{tabular}{|l|l|}
\hline $\begin{array}{l}\text { July 19, } \\
1955\end{array}$ & $\begin{array}{l}\text { The rapid rehabilitation of transportation and irrigation facilities, which has been the principal } \\
\text { accomplishments of the regime in recent months, demonstrated the DRV's ability to mobilize } \\
\text { large pools of unskilled manpower. (National Intelligence Council 2005: 78) }\end{array}$ \\
\hline $\begin{array}{l}\text { May 14, } \\
1957\end{array}$ & $\begin{array}{l}\text { Agricultural rehabilitation is fundamental to the recovery and development of all sectors of the } \\
\text { North Vietnamese economy and it has been the most important program of the regime...there } \\
\text { have been striking achievements in irrigation and flood control. (National Intelligence Council } \\
\text { 2005: 115) }\end{array}$ \\
\hline $\begin{array}{l}\text { May 26, } \\
1959\end{array}$ & $\begin{array}{l}\text {..the Hanoi leaders seem to have begun their planning with full attention to the basic importance } \\
\text { of agriculture in their economy. As a result they are emphasizing investment in irrigation....North } \\
\text { Vietnam has ended its rice imports and has even exported small amounts. (National Intelligence } \\
\text { Council 2005: 129-130) }\end{array}$ \\
\hline
\end{tabular}

Table 1: Central Intelligence Agency reports on irrigation development. Source: National Intelligence Council. 2005.

These same state-building rationalities extended into the post-war period with the establishment of the current Socialist Republic of Vietnam. Here, the new nation-state faced three main problems: "...how to develop rural areas in order to curb uncontrolled urbanization, how to achieve national food security for a growing number of people and how to develop and modernise rural areas to stabilise them politically" (Benedikter 2014b: 37). The solution to these foundational challenges? Irrigated agriculture. A 1977 World Bank report, written at the genesis of Bank involvement in Vietnam, states that "the clear priority of the Government's development program is agricultural development...with investment initially being concentrated on irrigation infrastructure" (World Bank 1977: 53). In Vietnam, irrigation is generally taken broadly to include all of the components supporting irrigation - not only irrigation channels, but also the pumping stations, drainage functions, dams and reservoirs, and water retention pools that make up the entire system. Irrigated agriculture thus represented an entire set of water management programs.

The new nation continued to incorporate irrigation infrastructure as a main pillar of its development. A 'rice everywhere' campaign promoted the establishment of irrigation across the country, addressing multiple challenges with one initiative (Hoanh et al. 2014). First, irrigation contributed to social and political stabilization, being "focused primarily to occupy the labour force... as the government feared that a free labour force might result in or contribute to the country's political instability" (Hoanh et al. 2014: 68). Public labor campaigns were organized by new irrigation authorities at provincial and district levels to harness available manpower for work on canals, embankments and irrigation channels (Benedikter 2014b). Second, the spread of irrigation was also a way of institutionalizing the new communist systems (Hoanh et al. 2014). Labor conducted on these irrigation schemes was reimbursed with stamps under the subsidy system, which could be redeemed for food and other goods. In practice, however, there were often shortages and a quite limited selection of goods available. In addition, subsequent management of irrigation systems by cooperatives or districts shifted decision-making away from households in line with collectivization policies (Benedikter 2014b). Finally, as described as some of the earliest priorities of the state, irrigation works were also central in securing food security for the population. Through these multiple rationalities and pathways, "water was capitalised by the new regime in order to create a new social order based on socialist institutions led by the oneparty state" (Benedikter 2014b: 41). Thus, in irrigation schemes, several state-building goals - political 
stabilization and institutionalization as well as food security - were served through water management schemes at a time when resources were very limited.

While domestic rationalities of state-building initially drove these irrigation programs, global rationalities of high modernist development fueled their proliferation. In this more recent iteration, high modernist rationalities were ushered in through the revolutionary communist government, which espoused "the rational design of social order" including "an increasing control over nature" (Scott 1998: 89). This continued adherence to high modernist rationalities - now linking to global communist movements - contributed in the water sector to a 'hydraulic bureaucracy' emerging in Vietnam. Literature on bureaucracies instantiated through water management - hydraulic bureaucracies - boomed after Wittfogel's provocative (1957) thesis that administering water control could lead to authoritarian styles of government. This line of argument, while heavily critiqued, continues to inspire scholarship on the relationship between political authorities and water management (Molle et al. 2009; Obertreis et al. 2016). It has continued to be influential in literature on Vietnam due to the tight linkages between water management and its experts, political authority, and the lived water environment (Benedikter 2014a, 2014b; Biggs 2008, 2012; Biggs et al. 2009; Evers and Benedikter 2009; Fforde 2010; Reis 2012; Reis and Mollinga 2015).

The culmination of this long history of translation of political rationalities into water management programs was the establishment of a hydraulic bureaucracy in Vietnam. The hydraulic bureaucracy is characterized by well-established, influential hydraulic institutions and extensive hydraulic works and policies. Hydraulic institutions in Vietnam manage water levels and flows, maintain and operate hydraulic infrastructure, and design and construct new hydraulic interventions. They are an integral part of daily life - from the water on tap, to the seasonal flooding and draining of rice paddy, to protection from storms. While adaptive approaches are gaining renewed traction in Vietnam, high modernist approaches grounded in a faith in technical solutions and mastery of nature remain paramount (Biggs et al. 2009; Mollinga 2008). Huge government expenditures, representing multiple percentage points of the government's own budget, go into maintaining and extending water management infrastructure. The vast majority of all water use in Vietnam is accounted for by irrigation (Evers and Benedikter 2009). Water management secures entire cities, regions, crops and exports. It has become foundational for Vietnamese society as it is currently ordered. This, however, again illustrates the difference in rationalities emerging from global rather than domestic scales. Intensive programs of water management driven by high modernist rationalities are often at odds with natural waterscapes and must be constantly maintained (Biggs 2012: 37-38), creating an infrastructural juggernaut upon which the current Vietnamese society and economy is dependent.

Political rationalities of water management in Vietnam have changed over time, prompting shifts in concrete hydraulic programs and the lived environment. Such programs have so changed local conditions environmental, institutional, and economic - that in some areas it would be extremely difficult and costly to shift away from them. This illustrates the extent to which water management programs in Vietnam have organized the lived environment to conform to dominant political rationalities, demonstrating the inherent power of rationalities and those who wield them. Political rationalities have also been re-scaled in the domestication of global rationalities. In Vietnam, this is evident in the domestic adoption and institutionalization of global high modernist rationalities over the course of decades (Benedikter 2014b; Biggs 2012). Together, these two points indicate that political rationalities from various scales powerfully shape dominant understandings of the environment and how authorities act upon it (and the societies that inhabit it) through concrete programs. This history - and its physical legacy - sets the stage for current climate change adaptation initiatives.

\section{Scaled rationalities in climate change programs}

The rationalities influencing historical water management in Vietnam shape present programs of water management as adaptation. This section outlines how current water management programs identified as adaptation more clearly reflect these historical, domestic(ated) rationalities and their outcomes, rather than novel global climate change adaptation agendas. 


\section{The water management and climate change context}

The water management interventions of the past and the rationalities that drove them have transformed Hue Province through myriad hydraulic programs. The development of water management in Hue Province has occurred on the backdrop of a complex water environment influential for life and livelihoods in the province. The province's main river, the Huong River, has a basin that extends over half of the province's area and is characterized by a complex hydrology, where the western mountains swiftly descend to lowlands and the eastern shore (JICA 2017). This water environment is managed through extensive infrastructure systems:

In the field of irrigation, a total of over 550 constructions have been built in the province, including two saltwater intrusion prevention dams (Thao Long and Cua Lac), two medium-sized reservoirs (Hoa My and Truoi), 251 small-sized reservoirs, hundreds of small dams at mountainous districts, and 295 small and medium-sized electrical pumps in the plains. Moreover, four large reservoirs Ta Trach, Binh Dien, Co Bi and A Luoi are under construction. (Hue People's Committee 2007: Part $\mathrm{I}^{2}$ )

Dams, canals, pumps, and reservoirs are interposed across the landscape and, in some areas, unite to form a closed water system tenuously linked to its surroundings by systems of pumps and inevitable precipitation (Huong Phong Commune 2015). Current programs focus on optimizing existing systems, completing major projects seen as cornerstones of the province's water management (DARD 2015b), securing the availability of adequate fresh water resources, preventing flooding and, to a lesser extent, on generating electricity (Hue People's Committee 2007; JICA 2017; Thao Long Management Company 2015).

These systems of hydraulic control support the fulfilment of high modernist development rationalities. In the words of the Province's Irrigation Master Plan, they support Hue's "potential to develop the general economy and the opportunity for economic growth in the period 2005-2010 and from 2011-2020" (Hue People's Committee 2007: Part III). They allow for agricultural intensification, especially on land otherwise unsuited to intensive agriculture, supporting the usually poorer population living in these areas. They also improve physical and economic security from flooding and extreme events and help provide a more constant, reliable flow of fresh water for residents for daily use as well as for industry (CCAP 2012; Hue People's Committee 2007). Such infrastructural programs support an above average provincial growth rate and a growth rate in the agricultural sector of over 4 percent 'despite difficult conditions' (Hue People's Committee 2007).

Beyond embodying ideals of managing the environment as an input to development, these water management systems create the context within which current adaptation operates. Climate change is significantly affecting daily life in the province in a variety of ways. Some of the points highlighted in the Province's Climate Change Action Plan (CCAP) include increasing frequency, intensity, fluctuations, and extremes in 'dangerous weather phenomena' as well as swings in temperature, water inundation and shortages, and salinity intrusion (2012). This range of impacts is seen to affect everything from human health and safety to industrial and agricultural production. Importantly, these issues are generally problematized as issues of water management rather than unsuitable development trajectories, so critical reflection on the premises of high modernist development is sidelined in favor of finding the proper technical solutions (CCAP 2012). This reflects a broad tendency towards depoliticization in dominant climate change adaptation approaches (Lindegaard 2018; Nightingale et al. 2019; Swyngedouw 2010: 64-65; Taylor 2015: 51-52).

Among the climate change impacts in the province are increasingly drastic and frequent extremes in temperatures and precipitation, which contribute to flooding on the one hand and water shortages and droughts on the other. The latter have become a more or less annual occurrence with major repercussions for socioeconomic development (Hue People's Committee 2007). From 1993-1994, droughts damaged almost 13,000 ha of rice (out of roughly 48,500 ha (GSO 2017)), leading to an estimated loss of 20,000 tons of paddy (CCAP 2012); and during the dry season of 2002, salinity intrusion into the Province's Huong River System extended up to $30 \mathrm{~km}$ inland. Due to such severe saltwater intrusion, the tap water of the entire city of Hue, located roughly $10 \mathrm{~km}$ upriver of the coast with a population of over 300,000, sometimes turned salty in the dry season

\footnotetext{
${ }^{2}$ When citing from a translated document, I provide the section number rather than the page number.
} 
(DARD 2015b). This drier weather was also problematic for local rice production, especially the second rice crop, which is typically planted long after the deluge of the rainy season had drained out into the rivers, brackish lagoon, and ocean (Thuan Hoa 2014).

To deal with climate change impacts, sub-national officials at provincial, district, and commune levels have sought to improve irrigation infrastructure. Provincial planning documents clearly illustrate the linkage between climate change adaptation and irrigation infrastructure. An advocacy document on raising climate change awareness produced by the provincial Department of Natural Resources and Environment (DONRE) discusses "using water resources effectively in the irrigation system taking into consideration the impact of climate change" and "programs to implement irrigation management methods on rice fields" amidst a general focus on larger-scale projects (DONRE 2013a). Furthermore, the CCAP (2012) mentions irrigation over thirty times, and the provincial irrigation master plan states: "due to the extreme changes of weather, heavy rains, prolonged drought, floods caused by typhoons, flash floods, landslides, etc., the irrigation and water supply capacity, flood control, and a program of completing the existing irrigation constructions should be reviewed" (Hue People's Committee 2007). Related irrigation programs include major dams currently under construction in the mountainous areas of the province, which provide reservoirs, and concreting irrigation channels to optimize use of available fresh water.

Irrigation programs function as a critical adaptation tool. They are communicated as being a way to mediate the impact of climate change on provincial development, reflecting the continued influence of the rationality of modernist development. The CCAP specifically includes a section on irrigation under 'Socioeconomic development planning in Thua Thien Hue province in 2015 and orientations towards 2020' (CCAP 2012). This focus is also evident in the irrigation master plan, which notes:

Due to the natural conditions with risks caused for the economy in the past few years and the impact of irrigation schemes in the province area, in order to grow and develop the economy in a sustainable way, Thua Thien Hue needs to develop irrigation, especially the construction of works for integrated use. (Hue People's Committee 2007: Part III)

In a setting of intensifying climatic changes, irrigation programs are thus presented as a way in which political authorities retain control of the environment and continue on the pathway of modernist development.

\section{Thao Long Dam}

The specific case of Thao Long Dam is illustrative of these political impetuses as well as of the complex historical dynamics and rationalities of current adaptation. Thao Long Dam is a roughly $600 \mathrm{~m}$ wide barrage dam (composed of a series of gates) by the mouth of the Huong River. It sits as a gatekeeper, strategically releasing or retaining the fresh water that drains from the Huong River System. Particularly, it prevents the incursion of saline water inland during the dry season, protecting freshwater resources for irrigation, industry, and domestic consumption. It is presented as having "thoroughly controlled" the province's "salinization situation" (CCAP 2008: 82). The importance of this is evident in the province's CCAP, which notes that "[o]ne of the greatest and the most specific effects of climate change on water resources in Thua Thien Hue is the expanding range of the influence of salinity intrusion" (CCAP 2012: 82). Thao Long follows on the heels of earlier salinity prevention interventions (Hue People's Committee 2007; Thao Long Management Company 2015). The previous construction at the mouth of the Huong River, built before 1970 and repaired after reunification, was rudimentary, composed of a cement and stone foundation and an array of wood attached to cement poles to form the dam (Thao Long Management Company 2015; Hue People's Committee 2007). Consequently, the dam could not be opened to allow floodwaters to escape, and the wooden barrage was eventually penetrated by saline water, becoming, in the words of one water management director, "completely useless" (Irrigation Management Company No. 5 2015). Thao Long Dam, completed in 2007, was built in its wake.

The case of Thao Long Dam seems clear-cut. It is presented in official documents as a key infrastructural solution to managing the province's climate change challenges. Yet what emerged in interviews with government officials was something else entirely. The dam was first conceived of in the 1980s as part of a vast 
provincial water management scheme, typifying the high modernist planning approaches of both colonial and communist governments. In this scheme major upland dams would be built to create reservoirs to store additional freshwater that could then be released slowly during the dry season. Thao Long would help retain this released water and prevent incursion of brackish water, securing freshwater for the secondary and tertiary irrigation canals - and a second rice crop - as well as for industry and domestic consumption. It could also be opened to allow for drainage of upstream floodwaters, which is important in a situation of increasingly extreme and erratic rainfall events. This system would provide the hydraulic engineering necessary to ensure continued exploitation of water resources to support the planned development of the province.

The development of this master scheme began at a time where Vietnam was undergoing profound transition. Critical shortages of food and the means of production had contributed to crisis, and the reform policies of the 1980s were praised as having "brought the country out of crisis and bankruptcy and saved its people from starvation" (Nguyen 2006: 332). It was in this setting that a far-reaching hydrological intervention was framed, yet funds were lacking. The province requested financial support from the national government, which supported the concept. This was unsurprising in light of the national government's stated goals of economic growth and considering the development challenges posed by salinity intrusion. The dam project also incorporated a bridge, which has helped link peripheral coastal areas to the rest of the province, another important contribution to rural development. However, the national government, in the face of seeming overwhelming resource demands across the country, only provided financial support after the increasing agricultural devastation resulting from droughts in the mid-1990s.

The initial steps for the project were undertaken from the late 1990s under the purview of the Ministry of Agriculture and Rural Development (MARD), with the Ministry of Construction also involved. These steps included the pre-feasibility study, project appraisal, feasibility study, design, and design appraisal, with each of these six phases involving a different consultancy or design company (some if not all of which were likely government companies) (Irrigation Management Company No. 5 2015). An environmental impact assessment was not required at the time and was not conducted, perhaps reflecting high modernist approaches to the subjection of nature (Thao Long Management Company 2014). Project construction began in 2001, ending in 2007. The dam went into operation under the responsibility of the Department of Agriculture and Rural Development (DARD), the line ministry of MARD at the provincial level, and under the direct management of Central Vietnam's semi-public Irrigation Management Company No. 5 (ibid). A department within the company was established to oversee the everyday operation of the dam, consisting of management, technical staff, and administrative personnel. This example of design, construction, and management illustrates Vietnam's extensive hydraulic bureaucracy.

The dam has indeed helped with issues of salinity intrusion. During the dry season, the dam is able to manage water flow quite precisely by opening and closing one or more of its 15 gates as needed; during the rainy season, some or all of the gates can be opened to allow runoff to drain. This has aided industry, tourism, and agriculture in the province, as well as daily life (CCAP 2012). Locally, the dam has also transformed almost 300 hectares of marginal agricultural areas close to the sea, with 274 ha converted from single to double rice cropping and 8 ha of previously unused land now being farmed (Huong Phong Agricultural Cooperative 2015; Huong Phong Commune 2014).

Tracing the framing of this ostensible adaptation program captures the complexity of the process of translation from rationality to program. Such translation occurs not in a vacuum, but in a pre-existing policy and physical environment, which influences the formulation and subsequent portrayal of new programs. Thao Long Dam was framed in the transition from state-building to global high modernist rationalities. The initial conception of the program in the 1980s occurred against a backdrop of volatile national policy and lack of local development. In the 1990s, when the program framing coalesced, conditions were still severe. In 1993 - during the period of extreme drought in Hue - over half of Vietnam's population lived on less than US $\$ 1.90$ a day (compared to just 3 percent today) (World Bank 2017). Issues of basic development and subsistence were at the forefront of official concerns as political authorities sought to implement sweeping reforms and re-forge the socialist development path. At this time, water management programs in the province were generally smallscale. Interviews indicate that it was roughly at this time that the digging of irrigation infrastructure began to be mechanized (DARD 2015b). Yet the dam reflected a forward-looking vision of high modernist control of 
the province's water resources through a set of dams envisioned to one day be a controlled water environment in the province. By the time the dam was under construction in the 2000s, rationalities of economic development through high modernist management had come to the fore; concerns with subsistence had largely faded, and surpluses, industry, exports, and growth targets had gained ground. These provided a rubric upon which the government's high modernist development could be judged, and government legitimacy became increasingly linked to meeting economic targets (Thayer 2010). This is evident in the framing of Thao Long in current interviews with officials, who present the dam as a development intervention. Officials specifically highlight its ability to control salinity intrusion and retain fresh water, supporting economic development across sectors (DARD 2013, 2015a, 2014; Huong Phong Commune 2014, 2015).

In interviews, officials rarely linked Thao Long to rationalities of climate change adaptation (ibid). This likely reflects the fact that adaptation as a domestic political rationality emerged later in the dam's lifetime. In the 2000s, when Thao Long was built, climate change as a political agenda was still gaining momentum. The formulation of domestic policies on climate change commenced with the initial 2003 National Communication under the United Nations Framework Convention on Climate Change (GoV 2003), and it was only after the completion of the dam that more extensive national climate change policies were revealed (Zink 2013: 142157) - one in 2008, one in 2011, and two in 2012 (MONRE 2012). This process was largely donor-driven, yet reflected existing political interests. Donor-driven climate change policies and activities were seen as an opportunity to address what Vietnamese policy makers saw as more pressing needs (Zink 2013: 142). One of these may have undermined economic development due to salinity intrusion. The third sentence of the 2011 National Climate Change Strategy notes that: "Higher temperature and sea level rising will cause inundation and water salinity which can bring about negative effects on agriculture and high risks to industry and socioeconomic systems in the future" (GoV 2011: 1). This rebranding of existing interests as climate change adaptation is also evident at provincial level and within the specific program of Thao Long. At the provincial level, a Climate Change Action Plan was produced in 2012 in accordance with national (donor-driven) legislation, but mainstreaming across departments and sectors has been uneven (CCAP 2012; DONRE 2013b). Many of the departments with responsibility for sectors affected by climate change have quietly been dealing with it for years, and the 'actions' of the CCAP evidence rebranding of existing project proposals. With Thao Long, while sub-national officials highlight aspects of the dam that offer crucial adaptation functions, these functions are grounded in established rationalities of economic development. The representation of Thao Long as a central adaptation intervention for the province seems first to emerge in the CCAP of 2012, which can be traced back to a push from donors for climate change policies (Zink 2013: 142-157).

The rationalities evident across roughly thirty years from the conception of Thao Long Dam to its present portrayal have a long history. They draw on rationalities of security in the Red River Delta, which were translated into water management programs, and the territorial expansion of the Vietnamese, which spread these rationalities and programs to what is now Hue Province. They then extend through the high modernist visions of colonialism and communism and enter the near past of Hue Province at a time of political crisis and palpable need. Ultimately, a new rationality of climate change adaptation has emerged, yet only after program completion. Though Thao Long Dam is indeed a central adaptation initiative in the province in that it helps address climate change impacts, it was not formulated in reference to rationalities of adaptation. Instead, it can be seen as a provincial mascot of national political strategies, which are in turn linked to global climate change agendas through donors. The fact that it can be cast as adaptation illustrates how many adaptation initiatives overlap with broader development and environmental management rationalities and the reality that many government officials (as well as many others) have been conducting 'adaptation' for years, just not under that label. Excavating this history of rationalities is instructive and illustrates how governmental programs can grow out of a diversity of rationalities. This is especially true of large-scale interventions with a lengthier lifetime. In addition, the case illustrates how the label of climate change adaptation can be misleading. When viewing concrete programs as translations of governmental rationalities, the case of Thao Long suggests that they should be analyzed as expressions of shifting rationalities, intertwined across scales. 


\section{Adaptation: rationalities, scales, and implications}

The case of Thao Long Dam provides broader insights into climate change adaptation. First, it illustrates the weaknesses of the dominant rationalities driving global adaptation efforts. Their universalizing tendencies ignore that adaptation enters into diverse contexts shaped by historical rationalities and resulting programs (Taylor 2015: 17-18); this entails particular institutional structures and processes, approaches to environmental management, and socio-economic configurations, among other things. Approaching adaptation as a separate, decontextualized area of intervention, for instance as seemingly universally applicable technical solutions, can limit its relevance in light of pre-existing rationalities and programs.

Second, domestic(ated) rationalities dominate adaptation. This is especially evident in the context of strong political institutions in Vietnam, but suggests caution in gauging the reach of global rationalities and programs more generally. Rationalities behind Thao Long are largely domestic or domesticated ones of global origins. Those global rationalities that emerge in project framing have been domesticated at national and subnational scales over decades, through a process of rescaling political rationalities. The national planning organs, engineering programs, technical organizations, local management offices, and particular infrastructural interventions this entails illustrate how a global high modernist mindset has truly been taken up throughout the political and organizational landscape of Vietnam. It has melded with existing rationalities in what can be seen as a dual process of 'glocalization' (Swyngedouw 2004). Institutions, processes, and physical constructions both result from and reinforce this trajectory and continue to influence the room for formulation of new programs. In practice, this suggests that global climate adaptation rationalities that are not emic to or influential at the site of adaptation formulation, may have difficulty gaining traction in program formulation. However in Vietnam, this process of domestication is beginning to emerge in climate change adaptation. The Province's CCAP is a direct result of national policy requirements. National climate change policy in Vietnam, in turn, has been extremely donor driven. Donors have supported the drafting process and have provided funding contingent on the passing of national climate change legislation (Zink 2013: 142-157). Yet, policies reflect not only donor wish-lists, but also domestic interests, echoing similar findings from other countries showing how global adaptation policy processes are used as a vessel for domestic politics (Funder et al. 2018; Smucker et al. 2015).

A third important aspect that emerges from the case is the power dynamic evident in determining which rationalities come to be translated into programs. Programs "express and re-constitute physical, social, cultural, economic or political power relations" (Swyngedouw 2007: 10). In terms of scales, the comparative weighting of local versus global (or national, meso, community, household, etc.) rationalities, or the rescaling of these, will necessarily impact the framing of adaptation needs and solutions as well as outcomes and implications (Bulkeley 2005). In the case of Thao Long Dam, rationalities of climate change adaptation were added long after program formulation and implementation, reflecting a broader trend in Vietnam. An analysis of programs identified as climate change up to 2006 against 2007-2008 show that in the first period, only 35\% of programs were conceptualized specifically in terms of climate change, while in the subsequent period, $88 \%$ were (Zink 2013: 129). Thao Long Dam falls squarely in this first group. Officials have invoked adaptation only after its construction, seemingly in reference to the extension of global climate change policy interventions into the domestic political scene. Program formulation drew instead on domesticated rationalities of economic development through high modernist environmental control. Implementation then instantiated these rationalities through the built environment. The future of climate change adaptation programs in Vietnam and beyond, and the understanding and experience of climate change for those affected, is thus dependent on which rationalities inform adaptation programs. This question of 'which rationalities?' points to the power of those wielding rationalities in program formulation and suggests the need for further exploration of trusteeship (Li 2007: 4-5) and expertise (Rose and Miller 1992: 187-189) in climate change adaptation.

Finally, climate change adaptation programs have ramifications not only for adaptation, but also for governance more generally. Indeed, "state policies and interventions on climate change adaptation in development can be understood as a form of governmentality through which state agencies seek to assert control over rural citizens and resources" (Funder et al. 2017: 2). In the case study area, climate change adaptation initiatives lean heavily on water management infrastructure, which structures daily life and perpetuates certain forms of environmental control (Lindegaard 2018). They reinforce current pathways of development and associated social and political dynamics and disparities. They feed into authorities' efforts to "shape the beliefs 
and conduct of others...by acting upon their will, their circumstances or their environment" (Rose and Miller 1992: 175). The approach taken here situates climate change adaptation programs within broader efforts to order societies and environments. It forefronts the power dynamics of adaptation, which often fall victim to depoliticizing discourse and practices (Ojha et al. 2016; Swyngedouw 2010; Taylor 2015: 64-65).

\section{Conclusions}

The article formulates a joint political ecology and a 'problematics of government' (Rose and Miller 1992) analytical framework, which allows for a novel understanding of the interplay between scales, governance and program formulation in climate change adaptation. In this article, it entails a scaled, historical approach to understanding how diverging political rationalities shape climate change adaptation programs.

Program formulation is more heavily influenced by historical, domestic(ated) rationalities than by novel global agendas. This rebuffs understandings of climate change adaptation as a universal enterprise (Field et al. 2014). However, it also documents how political rationalities can be rescaled, gaining traction within new scales and thus factoring into subsequent program formulation. This is a contribution to existing literature of the politics of scale and rescaling, offering a new approach through which to apply scale to studies of governance.

The article also probes the power dynamics evident in programming. Water management and climate change adaptation programs reproduce the rationalities they instantiate. Those wielding rationalities in program formulation have power, and further exploration is needed of trusteeship and expertise in climate change adaptation in particular. This has implications beyond adaptation or water management. Such programs further the premises of the systems of governance that engender them, thereby extending existing power relations and discrepancies. This article thus joins emerging literature that highlights the inherently political nature of climate change adaptation (Eguavoen et al. 2013; Eriksen et al. 2015; Funder et al. 2018).

For policy and practice, the findings suggest a critical approach. Analyses of national adaptation policies have consistently indicated the major influence of international organizations and donors in their formulation, for instance in Zambia (Funder et al. 2018), Nepal (Ojha et al. 2016) and Vietnam (Zink 2013: 142-157). This poses a risk of the imposition of universal rationalities of adaptation that are unsuitable for local realities. In Zambia and Vietnam, national elites and politicians have to some extent exploited donor agendas for their own ends, incorporating their own political rationalities in adaptation policy. However, the role of localized rationalities remains limited. This is out of sync with the significance of situated, historical factors in both climate change impacts and adaptation programs. It indicates a mismatch between policy and practice that may well undermine efforts to respond to climate change.

\section{Bibliography}

Adger, W.N., N.W. Arnell and E.L. Tompkins. 2005. Successful adaptation to climate change across scales. Global Environmental Change 15(2): 77-86.

Agrawal, A. 2010. Local institutions and adaptation to climate change. In Mearns, R. and A, Norton (eds.). Social dimensions of climate change: equity and vulnerability in a warming world. Washington DC: World Bank. Pp. 173-198.

Amundsen, H., F. Berglund and H. Westskog. 2010. Overcoming barriers to climate change adaptation-a question of multilevel governance? Environment and Planning C: Government and Policy 28(2): 276289.

Artur, L. and D. Hilhorst. 2012. Everyday realities of climate change adaptation in Mozambique. Global Environmental Change 22(2): 529-536.

Ayers, J. and T.J. Forsyth. 2009. Community-based adaptation to climate change. Environment: science and policy for sustainable development 51(4): 22-31.

Bassett, T.J. and C. Fogelman. 2013. Déjà vu or something new? The adaptation concept in the climate change literature. Geoforum 48: 42-53.

Benedikter, S. 2014a. Extending the Hydraulic Paradigm: reunification, state consolidation, and water control in the Vietnamese Mekong Delta after 1975. Southeast Asian Studies 3(3): 547-587. 
Benedikter, S. 2014b. The Vietnamese hydrocracy and the Mekong Delta: water resources development from state socialism to bureaucratic capitalism. Berlin: LIT Verlag Münster.

Biggs, D. 2006. Reclamation nations: the US Bureau of Reclamation's role in water management and nation building in the Mekong Valley, 1945-1975. Comparative Technology Transfer and Society 4(3): 225246.

Biggs, D. 2008. Breaking from the colonial mold: Water engineering and the failure of nation-building in the Plain of Reeds, Vietnam. Technology and Culture 49(3): 599-623.

Biggs, D. 2012. Quagmire: nation-building and nature in the Mekong Delta. Seattle: University of Washington Press.

Biggs, D., F. Miller, F., C.T. Hoanh and F. Molle. 2009. The delta machine: water management in the Vietnamese Mekong Delta in historical and contemporary perspectives. In Molle, F., T. Foran and M. Käkönen (eds). Contested waterscapes in the Mekong region: hydropower, livelihoods and governance. London: Earthscan. pp. 203-225.

Brenner, N. 2001. The limits to scale? Methodological reflections on scalar structuration. Progress in Human Geography 25(4): 591-614.

Brocheux, P. and Hémery, D. 2009. Indochina: an ambiguous colonization, 1858-1954. Berkeley and Los Angeles: University of California Press.

Bryant, R.L. 1992. Political ecology: an emerging research agenda in Third-World studies. Political Geography 11(1): 12-36.

Bryant, R.L. 1998. Power, knowledge and political ecology in the third world: a review. Progress in Physical Geography 22(1): 79-94.

Bryant, R.L. and S. Bailey. 1997. Third world political ecology. London: Routledge.

Budds, J. and L. Hinojosa. 2012. Restructuring and rescaling water governance in mining contexts: the coproduction of waterscapes in Peru. Water Alternatives 5(1): 119-137.

Bulkeley, H. 2005. Reconfiguring environmental governance: towards a politics of scales and networks. Political Geography 24(8): 875-902.

Cartwright, A., J. Blignaut, M. De Wit, K. Goldberg, M. Mander, S. O'Donoghue and D. Roberts. 2013. Economics of climate change adaptation at the local scale under conditions of uncertainty and resource constraints: the case of Durban, South Africa. Environment and Urbanization 25(1): 139-156.

CCAP. 2012. Action Plan to respond to climate change in Thua Thien Hue by 2020 approved by Thua Thien Hue People's Committee. Thua Thien Hue.

Cima, R.J. 1987. Vietnam: a country study. Washington, DC: GPO for the Library of Congress.

DARD. 2013. Interview with Vice Head and Staff Member of the Department of Water and Irrigation Systems and Flood and Storm Control, Department of Agriculture and Rural Development.

DARD. 2014. Interview with Head of Agricultural Department, Department of Agriculture and Rural Development.

DARD. 2015a. Interview with Irrigation and Flood and Storm Control Section, Department of Agriculture and Rural Development (DARD).

DARD. 2015b. Interview with Vice Head of Irrigation and Flood and Storm Control Section, Department of Agriculture and Rural Development.

Dieu, N.T. 1999. The Mekong River and the struggle for Indochina: water, war and peace. Westport: Praeger.

DONRE. 2013a. Content on advocacy to raise awareness and responsibility of communities about climate change in Thua Thuen Hue Province. Hue: Provincial Department of Natural Resources and Environment.

DONRE. 2013b. Interview with Vice Head of the Department of Natural Resources, Weather and Climate Change, Department of Natural Resources and Environment. 
Eguavoen, I., K. Schulz, S. de Wit, F. Weisser and D. Müller-Mahn. 2013. Political dimensions of climate change adaption: conceptual reflections and African examples. Working Paper Series 120. Bonn: ZEF.

Ehlert, J. 2012. Beautiful floods: environmental knowledge and agrarian change in the Mekong Delta, Vietnam. Berlin: LIT Verlag Münster.

Eriksen, S.H., A.J. Nightingale and H. Eakin. 2015. Reframing adaptation: the political nature of climate change adaptation. Global Environmental Change 35: 523-533.

Evers, H.-D. and S. Benedikter. 2009. Hydraulic bureaucracy in a modern hydraulic society-strategic group formation in the Mekong Delta, Vietnam. Water Alternatives 2(3): 416-439.

Feitelson, E. and I. Fischhendler. 2009. Spaces of water governance: the case of Israel and its neighbors. Annals of the Association of American Geographers 99(4): 728-745.

Fforde, A. 2010. Vietnam: water policy dynamics under a post Cold War communism. Water Alternatives 3(3): 552-574.

Field, C., V. Barros, K, Mach, M. Mastrandrea, M.v. Aalst, W.N. Adger, D. Arent, J. Barnett, R. Betts, E. Bilir, J. Birkmann, J. Carmin, D.D. Chadee, A.J. Challinor, M. Chatterjee,W. Cramer, D.J. Davidson, Y.O. Estrada, J.-P. Gattuso, Y. Hijioka, O. Hoegh-Guldberg, H.Q. Huang, G.E. Insarov, R.N. Jones, R.S. Kovats, P. Romero-Lankao, J.N. Larsen, I.J. Losada, J.A. Marengo, R.F. McLean, L.O. Mearns, R. Mechler, J.F. Morton, I. Niang, T. Oki, J.M. Olwoch, M. Opondo, E.S. Poloczanska, H.-O. Pörtner, M.H. Redsteer, A. Reisinger, A. Revi, D.N. Schmidt, M.R. Shaw, W. Solecki, D.A. Stone, J.M.R. Stone, K.M. Strzepek, A.G. Suarez, P. Tschakert, R. Valentini, S. Vicuña, A. Villamizar, K.E. Vincent, R.Warren, L.L.White, T.J.Wilbanks, P.P.Wong, and G.W. Yohe. 2014. Technical summary of climate change 2014: impacts, adaptation, and vulnerability. Contribution of Working Group II to the Fifth Assessment Report of the Intergovernmental Panel on Climate Change Cambridge: Cambridge University Press/IPCC.

Fontenelle, J.-P. 2001. Water management decentralisation in the Red River Delta, Vietnam: an uncompleted transition process towards local governance. International Journal of Water 1(3): 380-396.

Forsyth, T.J. and N. Evans. 2013. What is autonomous adaption? Resource scarcity and smallholder agency in Thailand. World Development 43: 56-66.

Foucault, M. 1991. Governmentality. In Gordon, C., G. Burchell and P. Miller (eds.). The Foucault effect: studies in governmentality. Chicago: University of Chicago Press. Pp. 87-104.

Funder, M., C. Mweemba and I. Nyambe. 2018. The politics of climate change adaptation in development: authority, resource control and state intervention in rural Zambia. The Journal of Development Studies 54(1): 30-46.

GoV. 2003. Initial National Communication under the United Nations Framework Convention on Climate Change. Hanoi. Available from http://unfccc.int/resource/docs/natc/vnmnc01.pdf (accessed 29 March 2020)

GoV. 2011. National Strategy on Climate Change for the Period 2011-2020. Hanoi. Available from http://chinhphu.vn/portal/page/portal/English/strategies/strategiesdetails?categoryId=30\&articleId=100 51283. (accessed 29 March 2020)

GSO. 2017. Area of planted paddy in Thua Thien Hue Province in 1995. http://www.gso.gov.vn/default_en.aspx?tabid=778 (accessed 29 March 2020)

Hall, N. and Persson, A. 2017. Global climate adaptation governance: why is it not legally binding? European Journal of International Relations 24(3): 540-566.

Hardy, A.D. 2005. Red hills: migrants and the state in the highlands of Vietnam. Copenhagen: NIAS Press.

Hoanh, C.T., D. Suhardiman and L.T. Anh. 2014. Irrigation development in the Vietnamese Mekong Delta: towards polycentric water governance? International Journal of Water Governance 2(2): 61-82.

Hue People's Committee. 2007. Thua Thien Hue's overall irrigation development master plan to 2015 and vision to 2020 . 
Huong Phong Agricultural Cooperative. 2015. Interviews with officials from an agricultural cooperative in Huong Phong Commune, Huong Tra Town.

Huong Phong Commune. 2014. Interview with Commune Vice Head and Land Management official.

Huong Phong Commune. 2015. Interview with Head of Commune People's Committee.

Irrigation Management Company No. 5. 2015. Interview with the Director of the Provincial Irrigation Mangement Company.

Jasanoff, S. 2004. Heaven and Earth: the politics of environmental images. In Jasanoff, S. and M.L. Martello (eds.). Earthly politics: local and global in environmental governance. Cambridge: MIT Press. pp. 3152.

Javeline, D. 2014. The most important topic political scientists are not studying: adapting to climate change. Perspectives on Politics 12(2): 420-434.

Jeffers, J.M. 2011. The Cork City flood of November 2009: lessons for flood risk management and climate change adaptation at the urban scale. Irish Geography 44(1): 61-80.

JICA. 2017. Preparatory survey for the project for emergency reservoir operation and effective flood management using water related disaster management information system. Available from http://open_jicareport.jica.go.jp/pdf/12286605_01.pdf (accessed 29 March 2020)

Johnson, C. 2012. Toward post-sovereign environmental governance? Politics, scale, and EU Water Framework Directive. Water Alternatives 5(1): 83-97.

Juhola, S. and L. Westerhoff. 2011. Challenges of adaptation to climate change across multiple scales: a case study of network governance in two European countries. Environmental Science and Policy 14(3): 239247.

Kreft, S., D. Eckstein and I. Melchior. 2016. Global climate risk index 2017: who suffers most from extreme weather events? Weather-related loss events in 2015 and 1996 to 2015. Germanwatch Nord-Süd Initiative $\mathrm{eV}$.

Leary, N., J. Adejuwon, V. Barros, P. Batimaa, B. Biagini, I. Burton, S. Chinvanno, R. Cruz, D. Dabi, A. de Comarmond, B. Dougherty, P. Dube, A. Githeko, A. Abou Hadid, M. Hellmuth, R. Kangalawe, J. Kulkarni, M. Kumar, R. Lasco, M. Mataki, M. Medany, M. Mohsen, G. Nagy, M. Njie, J. Nkomo, A. Nyong, B. Osman, E. Sanjak, R. Seiler, M. Taylor, M. Travasso, G. von Maltitz, S. Wandiga and M. Wehbe. 2007. A stitch in time: lessons for climate change adaptation from the AIACC project. AIACC Working Paper No. 48. Washington, DC: AIACC.

Lebel, L., P. Garden and M. Imamura. 2005. The politics of scale, position, and place in the governance of water resources in the Mekong region. Ecology and Society 10(2): 18.

Li, T.M. 2007. The will to improve: governmentality, development, and the practice of politics. Durham: Duke University Press.

Lindegaard, L.S. 2018. Adaptation as a political arena: interrogating sedentarization as climate change adaptation in Central Vietnam. Global Environmental Change 49: 166-174.

Lipsky, M. 1980. Street-level bureaucracy: dilemmas of the individual in public services. New York: Russel Sage Foundation.

Lundqvist, L.J. 2016. Planning for climate change adaptation in a multi-level context: the Gothenburg Metropolitan Area. European Planning Studies 24(1): 1-20.

Miller, C.A. 2004. Climate science and the making of a global political order. In Jasanoff, S. (ed.). States of knowledge: the coproduction of science and social order. New York: Routledge. Pp. 46-66.

Molle, F. 2009. River-basin planning and management: the social life of a concept. Geoforum 40(3): 484-494.

Molle, F., P.P. Mollinga and P. Wester. 2009. Hydraulic bureaucracies and the hydraulic mission: flows of water, flows of power. Water Alternatives 2(3): 328-349.

Mollinga, P.P. 2008. Water, politics and development: framing a political sociology of water resources management. Water Alternatives 1(1): 7-23. 
MONRE. 2012. Introduction to several climate change policies in Viet Nam. Paper read at UNFCCC COP18/CMP8 Side Event, November 28, 2012, at Doha, Qatar.

Moss, T. and J. Newig. 2010. Multilevel water governance and problems of scale: setting the stage for a broader debate. Environmental Management 46(1): 1-6.

National Intelligence Council. 2005. Estimative products on Vietnam: 1948-1975. Pittsburgh: GPO. Available here.

Neumann, R.P. 2009. Political ecology: theorizing scale. Progress in Human Geography 33(3): 398-406.

Nightingale, A.J., S. Eriksen, M. Taylor, T.J. Forsyth, M. Pelling, A. Newsham, E. Boyd, K. Brown, B. Harvey, L. Jones, R. Bezner Kerr, L. Mehta, L.O. Naess, D. Ockwell, I. Scoones, T. Tanner and S. Whitfield. 2019. Beyond technical fixes: climate solutions and the great derangement. Climate and Development https://doi.org/10.1080/17565529.2019.1624495

Nguyen, P.A. 2006. State-society relations in contemporary Vietnam: an examination of the arena of youth. Asia Pacific Viewpoint 47(3): 327-341.

Norman, E., K. Bakker and C. Cook. 2012. Introduction to the themed section: water governance and the politics of scale. Water Alternatives 5(1): 52-61.

Norman, E.S. and K. Bakker. 2009. Transgressing scales: water governance across the Canada-US borderland. Annals of the Association of American Geographers 99(1): 99-117.

Obertreis, J., T. Moss, P.P. Mollinga and C. Bichsel. 2016. Water, infrastructure and political rule: introduction to the special issue. Water Alternatives 9(2): 168-181.

Ojha, H.R. S. Ghimire, A. Pain, A.J. Nightingale, D.B. Khatri and H. Dhungana. 2016. Policy without politics: technocratic control of climate change adaptation policy making in Nepal. Climate Policy 16(4): 415433.

Porter, G. 1993. Vietnam: the politics of bureaucratic socialism. Ithaca: Cornell University Press.

Potsdam Institute. 2013. $4^{\circ}$ Turn down the heat: climate extremes, regional impacts, and the case for resilience. Washington DC: World Bank.

Reis, N. 2012. Tracing and making the state: policy practices and domestic water supply in the Mekong Delta, Vietnam. Berlin: LIT-Verlag.

Reis, N. and P.P. Mollinga. 2015. Public policy and the idea of the Vietnamese state: the cultural political economy of domestic water supply. Asian Studies Review 39(4): 628-648.

Rose, N. 1999. Powers of freedom: reframing political thought. Cambridge: Cambridge University Press.

Rose, N. and P. Miller. 1992. Political power beyond the state: problematics of government. British Journal of Sociology: 43(2): 173-205.

Scott, J. 1998. Seeing like a state: how well-intentioned efforts to improve the human condition have failed. New Haven: Yale University Press.

Smucker, T.A., B. Wisner, A. Mascarenhas, P. Munishi, E.E. Wangui, G. Sinha, D. Weiner, C. Bwenge and E. Lovell. 2015. Differentiated livelihoods, local institutions, and the adaptation imperative: assessing climate change adaptation policy in Tanzania. Geoforum 59: 39-50.

Swyngedouw, E. 2004. Globalisation or 'glocalisation'? Networks, territories and rescaling. Cambridge Review of International Affairs 17(1): 25-48.

Swyngedouw, E. 2007. Technonatural revolutions: the scalar politics of Franco's hydro-social dream for Spain, 1939-1975. Transactions of the Institute of British Geographers 32(1): 9-28.

Swyngedouw, E. 2010. Apocalypse forever? Theory, Culture and Society 27(2-3): 213-232.

Taylor, M. 2015. The political ecology of climate change adaptation: livelihoods, agrarian change and the conflicts of development. London: Routledge.

Thao Long Management Company. 2014. Interview with the Vice Director and Head of the technical department of Thao Long management company, the Joint Stock Limited Company One Management and Exploitation of Irrigation of Thua Thien Hue Province. 
Thao Long Management Company. 2015. Interview with Vice Director of the Thao Long management company, the Joint Stock Limited Company One Management and Exploitation of Irrigation of Thua Thien Hue Province.

Thayer, C.A. 2010. Political legitimacy in Vietnam: challenge and response. Politics and Policy 38(3): 423444.

Thuan Hoa. 2014. Interviews with Thuan Hoa Village residents.

Uggla, Y. 2010. What is this thing called 'natural'? The nature-culture divide in climate change and biodiversity policy. Journal of Political Ecology 17: 79-91.

Urwin, K. and A. Jordan. 2008. Does public policy support or undermine climate change adaptation? Exploring policy interplay across different scales of governance. Global Environmental Change 18(1): 180-191.

Wittfogel, K.A. 1957. Oriental despotism: a comparative study of total power. New Haven: Yale University Press.

Wong, P.P., I.J. Losada, J.-P. Gattuso, J. Hinkel, A. Khattabi, K.L. McInnes, Y. Saito and A. Sallenger. 2014. Coastal systems and low-lying areas. In V.R. Barros, C.B. Field, D.J. Dokken, K.J. Mach, M.D. Mastrandrea, T.E. Bilir, M. Chatterjee, K.L. Ebi, Y.O. Estrada, R.C. Genova, B. Girma, E.S. Kissel, A.N. Levy, S. MacCracken, P.R. Mastrandrea, and L.L.White (eds.). Climate Change 2014: impacts, adaptation, and vulnerability. Part A: global and sectoral aspects. Contribution of Working Group II to the Fifth Assessment Report of the Intergovernmental Panel on Climate Change. Cambridge: Cambridge University Press/IPCC.

World Bank. 1977. The Socialist Republic of Viet Nam: an introductory economic report. http://documents.worldbank.org/curated/en/437531468132897917/pdf/multi-page.pdf

World Bank. 2017. Vietnam overview. http://www.worldbank.org/en/country/vietnam/overview (accessed June 23 2017).

Zink, E. 2013. Hot science, high water: assembling nature, society and environmental policy in contemporary Vietnam. Copenhagen: NIAS Press. 